\title{
Supervisory Board and Company Borrowing: The Case of Developing Economics
}

\author{
Desi Ilona ${ }^{1}$, Zaitul $^{2, *}$ and Ethika ${ }^{2}$ \\ ${ }^{1}$ Economics and Business Faculty, Universitas Putra Indonesia YPTK, Padang, Indonesia \\ ${ }^{2}$ Economics Faculty and Business, Universitas Bung Hatta, Padang, Indonesia
}

\begin{abstract}
The objective of this paper is to find out the effects of the independence and size of the supervisory board on company borrowing in a two-tier board system. Unlike prior studies, such as in the United States, the current study is conducted in a developing country that has adapted a Continental European System. This study uses panel data analysis for 1,981 observations of 283 Indonesian listed companies in the 2004-2010 period. The control variables are Return on Assets (ROA), quality of audit, age, size and firm growth. Before panel data analysis is run, the outlier and normality tests are used. In addition, test of random-effect or fixed-effect model is conducted. This work finds that supervisory board independence has a negative effect on company borrowing. Further, firm profitability has a consistent effect on company borrowing.
\end{abstract}

Keywords: Supervisory Board Independence, Supervisory Board Size, and Company Borrowing.

\section{INTRODUCTION}

Following the seminal contribution by Modigliani \& Miller (1958 and 1963), company borrowing has been attracting research attention (e.g., Ross, 1997; Shyu, 2013; Tarus \& Ayabei, 2016). Myers (1984) confirmed that the decision to use borrowing could minimize agency costs by restricting or persuading the management board to act in the interests of stockholders and making better investment choices. Harris \& Raviv (1990) believed that higher borrowing may lower the agency costs and enhance firm performance. The impact of borrowing on firm performance has been explored by previous researchers (e.g., Margaritis \& Psillaki, 2010; Dawar, 2014; Shyu, 2013). However, prior studies on the effect of supervisory board on company borrowing is scarce, particularly in countries that have adopted a two-tier board system.

Indonesia is one of the countries that has modified the implementation of the two-tier board system, where the supervisory and management boards are elected and terminated by shareholders (Zaitul and Ilona, 2018, 2019). The National Committee on Corporate Governance (NCCG) issued its first code in 2001and another in 2006. However, some countries have revised their code several times, such as the United Kingdom (UK) (Sulaiman, 2017) and Malaysia (Jaffar \& Abdul-Shukor, 2016). This is the first research that separates the data under the first code and the revised code in order to investigate the effect of supervisory board on company borrowing.

${ }^{*}$ Address correspondence to this author at the Economics and Business Faculty, Universitas Bung Hatta, Indonesia; Tel: +62-751-7051678;

Fax: +62-751-7055475; E-mail: zaitul@bunghatta.ac.id
Researchers have viewed borrowing from two perspectives: firstly, the conflict between shareholders and debtholders which goes down as leverage (Williamson, 1984). It leads to less information asymmetry (Ross, 1977), and is a tool for stakeholders to control the actions of management (Shleifer \& Vishny, 1997). It also improves company performance (Dawar, 2014). The second perspective is from Shyu (2013); and Atanasova, Gatev, \& Shapiro (2016). Shyu (2013) believes that higher borrowing signals poor performance of the company. Atanasova, Gatev, \& Shapiro (2016) added that borrowing destroys the ability of the company to compete aggressively.

Most prior studies on company borrowing have been from developed countries (Dawar, 2014). Also, only a few studies have investigated the role of the governance board in debt decisions (Atanasova et al., 2016), particularly in developing countries (Shan \& Xu, 2012; Kumar, Colombage, \& Rao, 2017). Rocca (2007) focused on company borrowing and firm value with governance structure as the moderating variable. Using Ghanaian companies, Bokpin \& Arko (2009) examined the effect of board governance on company borrowing. Al-Najjar \& Hussainey (2011) focused on UK companies to test the effect of board characteristics on company borrowing. Finally, Tarus \& Ayabei (2016) verified the role of composition of directors in company borrowing using 272 listed companies on the Nairobi Securities Exchange (NSE).

This work is organized into several sections. The first section discusses about the background of the study. The next section talks about the theoretical aspects of this topic. The third section explains the 
methodology used and the following section discusses the findings of this research. Finally, this paper provides a conclusion related to supervisory board and its effect on company borrowing.

\section{THEORETICAL ASPECT}

\subsection{Company Borrowing}

Company borrowing is an amount of capital from debtholders used to finance a company's growth. From the financial management concept, there is a matching principle which matches the type of the asset that would be financed by long-term or short-term capital. The short-term asset is preferably financed by shorttime capital (short-term debt) and a long-term asset would be financed by long-term capital (long-term debt or equity). The impact of company borrowing on the cost of capital and on company value has been a topic of much controversy and debate (Jordan et al., 1998). Currently, the theory of company borrowing is broad and can be categorized into three subjects: asymmetric information and signaling; agency cost; and tax-based theory.

The structure of the funds raised by a company result from the interactions between the willingness of external financiers to provide funds and the managers' preferences for certain types of financing (Huyghebaert \& Van de Gucht, 2007). Company borrowing has been a crucial aspect for a long time (Modigliani \& Miller, 1958; Atanasova, Gatev, \& Shapiro, 2016; Tarus Ayabei, 2016). Ever since Modigliani \& Miller (1958) published a debt irrelevance proposition, financial economists have advanced a number of leverage relevance theories to explain the variation in debt ratios across firms. In some theories, the existence of taxes and bankruptcy costs makes debt relevant (DeAngelo \& Masulis, 1980). Other theories note that agentprincipal conflict is created due to information asymmetry between directors who have more information than shareholders (Myers, 1984; and Ross, 1977). The next theory is the agency theory proposed by Jensen \& Meckling (1976), which is derived from the dispute between directors, outside stockholders and bondholders.

According to Jensen \& Meckling (1976), there is conflict among a company's various stakeholders. This conflict is typically: (i) between principal and agent; (ii) amongst principals; (iii) between stockholders and bondholders; and (iv) information asymmetry within the supervisory board and board of directors in a two-tier board. Indonesia is one of the countries that follows the two tier-board system. The board of directors has more information than the supervisory board. The board of directors uses that information to decide policies that benefit them at the expense of stakeholders. The board of directors has private information about the characteristics of the company's return stream or return opportunities (Myers \& Majluf, 1984). From one approach, the choice of the firm's capital acts as a signal to outside investors of the information held by insiders. From another approach, company borrowing is designed to mitigate inefficiencies in the firm's investment decisions that are caused by the information asymmetry between managers (insiders) and investors and creditors (outsiders). The main conclusion from the asymmetric information theories is the pecking order hypothesis (POT) (Myers, 1984). Myers (1984) noted that the financing behavior follows the POT - therefore, profitability would have a negative effect on company borrowing. Petersen \& Rajan (1994) documented that as the firm spends more time (age) in relationships with institutions, the amount of company borrowing decreases.

\subsection{Board Governance}

Variation in company borrowing could be explained by the agency theory (Jensen \& Meckling, 1976). Graham \& Harvey (2001) stated that corporate governance is related to the financing decisions or company borrowing. Rocca (2007) argued that corporate governance has a significant role in ensuring reduced opportunistic behavior and constraints in information asymmetries and establishes specific skills in strategic decision-making. In addition, a better corporate governance framework could be an advantage for companies to access external financing and lower the cost of capital (Claessens, Djankov, Fan, \& Lang, 2002). Company borrowing is a manager's discretionery choice but managers tend to make decisions regarding company borrowing which maximize their own interests (Zwiebel, 1996).

The types of boards are classified into two: supervisory board and management board. Since the management board is choosen and fired by the supervisory board, the supervisory board has power to control the behavior of the management board and minimize agency conflict through the election of persons who are members of the management board. The supervisory board monitors and controls decisions made by the management board. Thus, company borrowing is indirectly influenced by the supervisory 
board composition (Tarus \& Ayabei, 2016). In reality, members of both boards are elected and fired by shareholders in Indonesia. It appears that the supervisory board lack powers to control the decisions made by the management board.

\subsubsection{Supervisory Board Independence}

The supervisory board is charged with controlling and monitoring the management board's actions. One of the members of the supervisory board is independent. Supervisory board independence refers to members who are not directly employed by the firm and have no psychological or economic affiliation with its management or the company (Baysinger \& Butler, 1985). The agency theory (Jensen \& Meckling, 1976) contends that boards with a notable number of independent members limit the exercise of managerial discretion by using ratification and controlling activities. Mishra \& Nielsen (2000) argued that the presence of indepedent board members increases the preservation of stockholders' interests by improving the effectiveness of decision-making and monitoring. Supervisory board independent members are believed to be strong because they are minimally affected by the management board (Maug, 1997). Hermalin \& Weisbach (1991) revealed that a higher number of supervisory board independent members will act in the best interests of stockholders. However, supervisory board independence may not play an effective role in the supervision of management board members in reducing uncertainties in company value (Darmadi \& Gunawan, 2013). Hence, board independence is very much related to executive decisions.

Bhojraj \& Sengupta (2003) stated that a company with higher supervisory board independence has lower bond yields and higher credit ratings on new debt issuances. This condition will reduce cost of debt and make issuance of equities less desirable. Hendry \& Kiel (2004) noted that higher supervisory board independence, thereby allowing supervisory board independence mere rubber stamps. As a supervisory board with high independence is assumed to be a powerful board, Harford, Li, \& Zhao (2008) argued that a powerful supervisory board is associated with greater borrowing due to its effectiveness in monitoring the management board.

Jensen (1986) said that management board will utilize more debt in order to turn down the number of free cash flows available for discretionary spending. The resource-dependence theory states that the management board can promote higher borrowing because of the networking of members. The management board has access to providers of loans. However, the supervisory board does not have all the information on opportunistic management board behavior. More effective control and monitoring by supervisory board members can reduce the intention of the management board to have more borrowing for company operations. Abidin, Ahmad-Zaluki, \& Ilona (2011) found that the association between supervisory board independence and company performance is negative and significant in the Indonesian context. However, Abor (2007) documented that there is a positive relationship between supervisory board independence and company borrowing. Further, Tarus \& Ayabei (2016) found a positive effect of supervisory board independence on company borrowing. Based on the explanation above, the first hypothesis is as follows:

H1: Higher number of supervisory board independence creates low level of company borrowing

\subsubsection{Supervisory Board Size}

The total number of members on the supervisory board in a company refers to supervisory board size. Jackling \& Johl (2009) commented that supervisory board size plays an important role in improving corporate governance practices. From the resourcesdependence perspective, Pearce \& Zahra (1992) concluded that a large number of board members may benefit a company because they would provide a link to the external environment to secure important resources. In other words, more board members means they can link the company to loan-providers and hence, increase company borrowing. However, Berger, Eli, \& Yermack (1997) stated that a bigger board results in lower level of leverage. This argument is from a managerial entrenchment perspective, where members of a small board have more active oversight towards reducing management entrenchment. In addition, Berger et al. (1997) said that management with less rentrenchment tends to enggage in higher leverage. However, Jensen (1986) stated that debt financing will limit managerial flexibility by lessening free cashflow and controlling the managers' ability to increase their compensation. Furthermore, a very big supervisory board can lead to less communication among members due to the time taken to get them altogether at the same time. This is supported by Van Essen, Engelen, \& Carney (2013) who concluded that 
a very big supervisory board is ineffective. Therefore, smaller supervisory boards are effective in controlling and influencing management decisions and yielding lower leverage.

Using 847 small-cap companies in Canada, Atanasova, Gatev, \& Shapiro (2016) found that there is a positive relationship between board size and company borrowing. Anderson, Mansi, \& Reeb (2004) reported that larger size of boards yields lower cost of debt and motivates managers to use more debt. Meanwhile, Abor (2007) and Reddy, Locke, \& Scrimgeour (2010) declared a positive effect of board size on company borrowing . Fosberg (2004) concluded that companies using a two-tier leadership structure have high debt to equity ratio. In addition, Reddy et al. (2010) concluded that larger boards have higher expertise, more management monitoring and wider access to a range of contracts and resources. Therefore, this condition makes a company able to achieve better access to equity markets, thus leading to lower levels of borrowing. Bokpin \& Arko (2009) and $\mathrm{Su}$ (2010) concluded that board size is positively related to company borrowing. However, Wiwattanakantang (2001) found that there is no significant link between board size and debt to equity ratio. Based on the theory and previous studies, the following hypothesis is developed.

$\mathrm{H}$ 2: A larger number of supervisory board members creates more leverage

\section{RESEARCH METHOD}

This investigation explores Indonesia's listed companies from 2004 to 2010. Data was collected from companies' website, Indonesia's Stock Exchange (IDX) website and other electronic sources. Data was analyzed using panel data approach. Outliers were detected and remedied using Grubbs' (1969) procedure. Classical assumptions, such as normality, multicollinearity and heteroskedasticity were applied before regression was run (Hair, William, Babin, \& Anderson, 2014). The White test was used for heteroskedasticity problem. Different group means and Breusch-Pagan and Hausman test were used to check whether the model is pooled OLS, random-effect or fixed-effect.

Company borrowing was proxied by leverage, measured by total debt divided by total assets (Rajan \& Zingales, 1995; Shyu, 2013). Supervisory board independence refers to the number of supervisory board independent members divided by total number of supervisory board members (Tarus \& Ayabei, 2016). Further, supervisory board size was identified by the number of supervisory board members in the company (Shan \& Xu, 2012). Quality of audit was detected by using a dummy variable; if the annual report of the company shows it was audited by big 4 audit firm, it was given 1 and 0 otherwise ( $\mathrm{Wu}, 2012)$. Total assets were employed to identify company size (Abor \& Biekpe, 2005). Further, the number of years since a company started its business was used as company age (Ezeoha \& Okafor, 2010). This study used sales for current year less sales in previous year divided by sales in previous year to measure company growth (Dawar, 2014). The analysis began with the normality test, followed by multicollinearity and heteroscedasticity. Finally, the data was reggressed using the panel data procedures. The research model is as follow.

$C B=\alpha+\beta_{1} \mathrm{Bl}_{\mathrm{it}}+\beta_{2} \mathrm{BZ}_{\mathrm{it}}+\beta_{3} \mathrm{FO}_{\mathrm{it}}+\beta_{4} \mathrm{ROA}_{\mathrm{it}}+\beta_{5} \mathrm{QA}_{\mathrm{it}}+$ $\beta_{6} \mathrm{FS}_{\mathrm{it}}+\beta_{7} \mathrm{FA}_{\mathrm{it}}+\beta_{8} \mathrm{FG}_{\mathrm{it}}+\mathrm{e}$

Where as

$\mathrm{BI}$ : Supervisory board independence

BZ: Supervisory board sizeROA : Return on asset

QA : Quality of audit

FS : Firm size

FA: Firm age

FG: Firm growth

\section{CB: Company borrowing}

\section{EMPIRICAL RESULT}

This study used 283 companies listed on IDX. The descriptive statistics of the research variables are shown in Table 1. Mean value of company borrowing is $55.12 \%$. Furthermore, company leverage is higher in Indonesian companies compared to a prior study of Hussainey \& Aljifri (2012) from the United Arab Emirates (UAE). They found mean value of leverage is $36 \%$. Proportion of supervisory board independence is 0.38 which is not diffrent from Reddy \& Locke (2014). The mean value of supervisory board size is four persons which is smaller than that found in a prior study by Tarus \& Ayabei (2016), who found the average board size is 8.46 . The other variables are control variables, where average value of Return on 
Table 1: Statistic Descriptive

\begin{tabular}{|c|c|c|c|c|c|}
\hline Variables & Mean & Median & Std & Min & Max \\
\hline \hline BI (proportion) & 0.38 & 0.34 & 0.13 & 0.00 & 1.00 \\
\hline BZ (person) & 4.17 & 4.00 & 1.97 & 2.00 & -56.50 \\
\hline ROA (\%) & 5.26 & 2.37 & 53.01 & 0.00 & 1.00 \\
\hline QA (big 4) & 0.39 & 0.01 & 0.46 & 0.56 & $237,567.00$ \\
\hline FS (Rp billion) & $7,135.51$ & 716.37 & $12,277.07$ & 3.00 & 128.00 \\
\hline FA (years) & 29.05 & 28.00 & 17.12 & -156.05 & 127.35 \\
\hline FG (\%) & 29.23 & 14.11 & 54.25 & -65.67 & 179.00 \\
\hline CB (\%) & 55.12 & 50.12 & 34.23 & \\
\hline
\end{tabular}

Notes: $\mathrm{BI}=$ Supervisory board Independence, $\mathrm{BZ}=$ Supervisory board Size, ROA= Return on Asset, QA= Quality of audit, FS = Firm Size, FA= Firm Age, FG= Firm Growth, and $\mathrm{CB}=$ Company Borrowing.

Assets (ROA) is $5.26 \%$ with minimal and maximal values of $-56.50 \%$ and $67.02 \%$, respectively. About $39 \%$ (110) of the 283 companies were audited by Big 4 audit firms. Firm size measured by total assets varies from Indonesian Rupiah (IDR) 0.56 billion to IDR $237,567.00$ billion. The mean age of firm is 29.05 years. In addition, average value of firm growth is $29.23 \%$.

This study used skewness and kurtosis to detect normality. Abdul-Rahman \& Mohamed-Ali (2006) argued that data is said to be normal if skewness and kurtosis have absolute values of 1.96 . The rule of thumb is data that is normal will have the z-skewness and z-kurtosis value between -2 and +2 (Field, 2009). The result of this test shows that ROA, FS, FA, FG and $\mathrm{CS}$ are not normal. Thus, the data was tranformed into natural logarithm and square root (Tabacknick \& Fidell, 1996). Table 2 explains the result of multicollinearity test. Pearson Correlation was examined to see whether or not there is a multicollinearity problem in the model. Gujarati (1995) argued that multicollinearity problem exists if Pearson Correlation exceeds 0.80 . The result of Pearson Correlation in Table 2 shows that there is no multicollinearity problem.

The main aim of this research is to verify the effect of supervisory board independence and supervisory board size on company borrowing. By applying panel data analysis, this study divided the analysis into full (2004-2010); first code (2004-2006); and renewed code (2007-2010) samples. In addition, the current research ran the data for Pooled OLS model, followed by the fixed-effect and random-effect models. The results of Pooled OLS regression are shown in Table 3 . In general, the fitness of model is adequate since all $\mathrm{F}$ Statistic are significant and below $1 \%$.

The relationship between supervisory board independence and company borrowing is consistently negative and significant for all samples, i.e., first code and renewed code data. It means that a higher number of supervisory board independent members produces lower company borrowing. Thus, the first hypothesis of

Table 2: Pearson Correlation

\begin{tabular}{|c|c|c|c|c|c|c|c|c|}
\hline Variable & BI & $B Z$ & ROA & QA & FS & FA & FG & CB \\
\hline $\mathrm{BI}$ & 1 & & & & & & & \\
\hline$B Z$ & -0.01 & 1 & & & & & & \\
\hline ROA & 0.00 & $0.11^{* *}$ & 1 & & & & & \\
\hline QA & 0,02 & $0.29^{* *}$ & $0.25^{\star \star}$ & 1 & & & & \\
\hline FS & $0.14^{* *}$ & $0.51^{\star *}$ & $0.12^{* *}$ & $0.44^{* *}$ & 1 & & & \\
\hline FA & 0,02 & $0.22^{* *}$ & $0.16^{* *}$ & $0.26^{* *}$ & $0.32^{* *}$ & 1 & & \\
\hline FG & 0.00 & 0,03 & $0.17^{\star *}$ & $0.07^{* *}$ & $0.13^{* *}$ & $-0,01$ & 1 & \\
\hline CB & $-0.05^{\star}$ & $0.09^{* *}$ & $-0.12^{* *}$ & 0,02 & $0.15^{* *}$ & $0.13^{* *}$ & 0,01 & 1 \\
\hline
\end{tabular}

Notes: ${ }^{* * *}, * *$ and ${ }^{*}$ indicate that a significant at $1 \%, 5 \%$ and $10 \%$ level, $\mathrm{BI}=$ Supervisory board Independence, $\mathrm{BZ}=$ Supervisory board Size, ROA= Return on Asset, $\mathrm{QA}=$ Quality of audit, FS = Firm Size, FA= Firm Age, FG= Firm Growth, and CB= Company Borrowing. 
Table 3: Result of Pool OLS Model

\begin{tabular}{|c|c|c|c|c|c|c|}
\hline \multirow{2}{*}{ Variables } & \multicolumn{2}{|c|}{ All Sample $n=1981$} & \multicolumn{2}{|c|}{ First Code $n=849$} & \multicolumn{2}{|c|}{ Renewed Code $n=1132$} \\
\hline & Coef & t stat & Coef & t stat & Coef & t stat \\
\hline Constant & 3.95 & $8.99^{* * *}$ & 2.54 & $3.74^{* * *}$ & 4.58 & $8.08^{* * *}$ \\
\hline $\mathrm{BI}$ & -1.10 & $-3.02^{* * *}$ & -1.34 & $-2.39^{* *}$ & -0.89 & $-1.76^{*}$ \\
\hline$B Z$ & 0.02 & 0.55 & 0.03 & 0.55 & 0.11 & $2.88^{* * *}$ \\
\hline ROA & -0.26 & $-6.68^{\star * *}$ & -0.37 & $-5.80^{* \star *}$ & -0.23 & $-4.61^{* \star *}$ \\
\hline QA & -0.16 & -1.36 & -0.18 & -0.99 & -0.18 & -1.24 \\
\hline FS & 0.16 & $4.91^{* * *}$ & 0.27 & $5.27^{\star \star *}$ & 0.07 & $2.00^{* *}$ \\
\hline FA & 0.49 & $5.01^{* * *}$ & 0.47 & $3.47^{* * *}$ & 0.52 & $3.69^{* * *}$ \\
\hline FG & 0.03 & 1.01 & 0.08 & $1.69^{*}$ & 0.01 & 0.21 \\
\hline F Sig & 0.00 & & 0.00 & & 0.00 & \\
\hline R square & 0.06 & & 0.11 & & 0.04 & \\
\hline
\end{tabular}

Notes: ${ }^{* * *},{ }^{* *}$ and ${ }^{*}$ indicate that a significant at $1 \%, 5 \%$ and $10 \%$ level. $\mathrm{BI}=$ Supervisory board Independence, $\mathrm{BZ}=$ Supervisory board Size, ROA= Return on Asset $\mathrm{QA}=$ Quality of audit, FS = Firm Size, FA= Firm Age, FG= Firm Growth, and CB= Company Borrowing.

this work is accepted. In contrast, supervisory board size shows a positive and significant impact on company borrowing only for the renewed code model. However, this model is not preferred because the model selection result shows that the fixed-effect model is more adequate.

Choice between Pooled OLS and fixed-effect using the joint significance of differing group means shows low p-value counts against the null hypothesis. Therefore, Pooled OLS model is adequate, over the fixed-effect alternative for all models. Further, the Pooled OLS and random-effect model using BreaushPagan test has low p-value counts against the null hypothesis, showing that the Pooled OLS model is adequate, over the random-effects alternative. The research also used the Hausman test to test which model is better, the random- effect or fixed-effect (Hausman, 1978). The result shows that fixed-effect model is more adequate. The next step was to test heteroskedaticity. The White General Heteroskedasticity test was employed (White, 1980). The finding shows that there is heteroskedasticity problem for all models (Table 4). Gujarati (1995) argued that heteroskedasticity problem can be remedied by using the White Heteroskedasticity Consistent Variance.

The next analysis was to regress the independent variables against the dependent variable by using the Heteroskedasticity Corrected Model. This study employed the fitness of model and all models are fit due to $\mathrm{F}$ significance being lesser than $5 \%$. As for the regression result, the effect of supervisory board independence is consistent for all models, whereby it has a negative impact on leverage as a proxy of company borrowing. It indicates that a higher supervisory board independence in a company, tends to minimize the use of leverage in firms' operations. This result contradicts the prior work of Tarus \& Ayabei (2016). Furthermore, the result of this paper supports the statement of $\mathrm{Yu}$ (2012) that a company uses less borrowing in a country which has poor corporate governance practices.

On the other hand, as for supervisory board independence result, a larger number of supervisory board members increased company borrowing in the renewed code period. Meanwhile, all control variables, except for quality of audit, have a significant and positive relationship with company borrowing for all

Table 4: White General Heteroskedasticity Test

\begin{tabular}{|c|c|c|c|}
\hline & All sample & First Code & Renewed code \\
\hline \hline Chi-Square & 191.51 & 72.06 & 184.29 \\
\hline P value & 0.00 & 0.00 & 0.00 \\
\hline Ho (Null) & Rejected & Rejected & Rejected \\
\hline
\end{tabular}


Table 5: Result of Heteroskedasticity Corrected Model

\begin{tabular}{|c|c|c|c|c|c|c|}
\hline \multirow{2}{*}{ Variables } & \multicolumn{2}{|c|}{ All sample, $n=1981$} & \multicolumn{2}{|c|}{ First Code, $n=849$} & \multicolumn{2}{|c|}{ Renewed Code, $n=1132$} \\
\hline & Coef & t stat & Coef & t stat & Coef & t stat \\
\hline Constant & 3.72 & $8.42^{* * *}$ & 2.78 & $4.37^{\star \star *}$ & 3.87 & $7.12^{* * *}$ \\
\hline $\mathrm{BI}$ & -1.31 & $-4.09^{* * *}$ & -0.95 & $-2.12^{\star *}$ & -0.13 & $-2.48^{* *}$ \\
\hline$B Z$ & 0.01 & 0.46 & 0.04 & 0.91 & 0.09 & $3.40^{* * *}$ \\
\hline ROA & -0.37 & $-10.07^{* * *}$ & -0.53 & $-8.18^{* * *}$ & -0.41 & $-9.05^{\star * *}$ \\
\hline QA & 0.24 & $-2.32^{* *}$ & -0.27 & $-1.69^{*}$ & -0.14 & -1.21 \\
\hline FS & 0.19 & $5.82^{* * *}$ & 0.27 & $5.68^{\star \star *}$ & 0.08 & $2.38^{\star *}$ \\
\hline FA & 0.49 & $5.53^{\star \star *}$ & 0.38 & $3.02^{* * *}$ & 0.78 & $6.68^{* * *}$ \\
\hline FG & 0.07 & $1.89^{*}$ & 0.12 & $2.55^{\star *}$ & 0.05 & 1.24 \\
\hline F Sig & 0.00 & & 0.00 & & 0.00 & \\
\hline $\mathrm{R}$ square & 0.09 & & 0.14 & & 0.11 & \\
\hline
\end{tabular}

Notes: ${ }^{* * *},{ }^{* *}$ and * indicate that a significant at $1 \%, 5 \%$ and $10 \%$ level. $\mathrm{BI}=$ Supervisory board Independence, $\mathrm{BZ}=\mathrm{Supervisory}$ board Size, ROA= Return on Asset, $\mathrm{QA}=$ Quality of audit, FS = Firm Size, FA= Firm Age, and FG= Firm Growth.

models. ROA, as proxy of firm profitability, significantly and negatively affects company borrowing for all models. This result indicates that the higher the firm's profitability, the lower the company borrowing. Quality of audit has a negative and significant impact on company borrowing. It indicates that a company's financial report audited by big 4 audit firm is likely to have lower company borrowing. This finding is supported by the prior study of Desai, Xu, \& Zeng (2016). However, this finding does not support the third model. In addition to firm size, big firms tend to have higher company borrowing compared to small firms. Firm age also has a positively significant effect on company borrowing, which implies that older companies are likely to use more debt. Finally, firm growth has a positive effect on company borrowing.

\section{CONCLUSION AND RECOMMENDATION}

Decision to use debt to finance a company's growth is increasingly becoming an issue in corporate finance. From the agency perspective, board goverance has a signifanct role in ratification and monitoring of the financing strategy implemented by management. In Indonesia's case, the supervisory board plays this role to get good governance outcomes. Company borrowing is a corporate governance mechanism to minimalize the conflict between shareholders and management. Using Indonesia's data, this study aims to investigate the relationship between supervisory board characteristics (independence and size) and company borrowing. The result shows that size of supervisory board has a positive effect on company borrowing only in the renewed code period. However, it is not an important factor that influences company borrowing for first code data. This finding implies that the phenomenon of company borrowing could be explained by the agency theory. Future researchers could expand this study by adding other corporate governance issues, structures and mechnisms that affect company borrowing. Future studies can also use corporate governance variables as moderating variables between company borrowing and company value as suggested by Rocca (2007). This study also has a practical implication in the sense that a company tends to have more debt, it is better to have more size of supervisory board.

\section{ACKNOWLEDGEMENT}

The authors are indebted to the Rektor of Universitas Bung Hatta and Universitas Putra Indonesia YPTK for encouragements and financial sponsor as well as the editor of IAC 2017 for their innumerable guidance, enlightening comments and helpful suggestions.

\section{REFERENCE}

Abdul-Rahman, R., \& Mohamed-Ali, F. H. (2006). Board, audit committee, culture and earnings management: Malaysian evidence. Managerial Auditing, 21(7), 783-804. https://doi.org/10.1108/02686900610680549

Abidin, S., Ahmad-Zaluki, N. A., \& Ilona, D. (2011). Board quality and the performance of Indonesian listed companies. Corporate Board: Role, Duties \& Composition, 7(1), 3-81. https://doi.org/10.22495/cbv7i1art5

Abor, J. (2007). Debt policy and performance of SMEs: evidence from Ghanaian and South African firms. The Journal of Risk Finance, 8(4), 364-379.

https://doi.org/10.1108/15265940710777315 
Abor, J., \& Biekpe, N. (2005). What determines the capital structure of listed firms in Ghana. African Finance Journal, 7(1), 37-48.

Al-Najjar, B., \& Hussainey, K. (2011). Revisiting the capital-structure puzzle: UK evidence. The Journal of Risk Finance, 12(4), 329-338. https://doi.org/10.1108/152659411111158505

Anderson, R. C., Mansi, S. A., \& Reeb, D. M. (2004). Board characteristics, accounting report integrity, and the cost of debt. Journal of Accounting and Economics, 37(3), 315-342. https://doi.org/10.1016/j.jacceco.2004.01.004

Atanasova, C., Gatev, E., \& Shapiro, D. (2016). The corporate governance and financing of small-cap firms in Canada. Managerial Finance, 42(3), 244-269. https://doi.org/10.1108/MBE-09-2016-0047

Baysinger, B. D., \& Butler, H. N. (1985). Corporate Governance and the Board of Directors: Performance Effects of Changes in Board Composition Corporate Governance and the Board of Directors: Performance Effects of Changes in Board Composition. Journal of Law, Economics, \& Organization, 1(1), 101-124.

Berger, P. G., Eli, O., \& Yermack, D. L. (1997). Management Entrenchment and Capital Structure Decisions. The Journal of Finance, 52(4), 1411-1438. https://doi.org/10.1111/j.1540-6261.1997.tb01115.x

Bhojraj, S., \& Sengupta, P. (2003). Effect of Corporate Governance on Bond Ratings and Yields: The Role of Institutional Investors and Outside Directors*. The Journal of Business, 76(3), 455-475. https://doi.org/10.1086/344114

Bokpin, G. A., \& Arko, A. C. (2009). Ownership structure, corporate governance and capital structure decisions of firms: Empirical evidence from Ghana. Studies in Economics and Finance, 26(4), 246-256.

https://doi.org/10.1108/MBE-09-2016-0047

Claessens, S., Djankov, S., Fan, J. P. H., \& Lang, L. H. P. (2002). Disentangling the Incentive and Entrenchment Effects of Large Shareholdings. The Journal of Finance, 57(6), 27412771.

https://doi.org/10.1111/1540-6261.00511

Darmadi, S., \& Gunawan, R. (2013). Underpricing , Board Structure , and Ownership: An Empirical Examination of Indonesian IPO Firms. Managerial Finance, 39(2), 181-200. https://doi.org/10.1108/03074351311294016

Dawar, V. (2014). Agency theory, capital structure and firm performance: some Indian evidence. Managerial Finance, 40(12), 1190-1206. https://doi.org/10.1108/MF-10-2013-0275

DeAngelo, H., \& Masulis, R. W. R. W. (1980). Optimal capital structure under corporate and personal taxation. Journal of Financial Economics, 8(1), 3-29.

https://doi.org/10.1016/0304-405X(80)90019-7

Desai, V., Xu, B., \& Zeng, T. (2016). Local accounting firms' pricing responses to entry of the Big Four accounting firms into China. Journal of Accounting in Emerging Economies, 6(1), 50-68.

https://doi.org/10.1108/JAEE-06-2013-0030

Ezeoha, A. E., \& Okafor, F. O. (2010). Local corporate ownership and capital structure decisions in Nigeria: a developing country perspective. Corporate Governance, 10(3), 249-260. https://doi.org/10.1108/14720701011051893

Field, A. (2009). Discovering statistic using SPSS. New York: SAGE.

Fosberg, R. H. (2004). Agency problems and debt financing: leadership structure effects. Corporate Governance: The International Journal of Business in Society, 4(1), 31-38. https://doi.org/10.1108/14720700410521943

Graham, J. R., \& Harvey, C. R. (2001). The theory and practice of corporate finance: Evidence from the field. Journal of Financial Economics, 60(2-3), 187-243. https://doi.org/10.1016/S0304-405X(01)00044-7
Grubbs, F. F. (1969). Procedures for Detecting Outlying Observations in Samples. Tachometric (Vol. 11). https://doi.org/10.1080/00401706.1969.10490657

Gujarati, D. (1995). Basic Econometric. Singapore: McGraw-Hill.

Hair, J. F., William, C., Babin, B. J., \& Anderson, R. E. (2014). Multivariate Data Analysis (7th Editio). Pearson Education Limited.

Harford, J., Li, K., \& Zhao, X. (2008). Corporate boards and the leverage and debt maturity choices. International Journal of Corporate Governance, 1(1), 1-48. https://doi.org/10.1504/IJCG.2008.017648

Harris, M., \& Raviv, A. (1990). Capital Structure and the Informational Role of Debt. The Journal of Finance, 45(2), 321-349. https://doi.org/10.1111/j.1540-6261.1990.tb03693.x

Hausman, J. A. (1978). Specification Tests in Econometrics. Econometrica, 46(6), 1251-1271. https://doi.org/10.2307/1913827

Hendry, K., \& Kiel, G. C. (2004). The role of the board in firm strategy: Integrating agency and organisational control perspectives. Corporate Governance, 12(4), 500-520. https://doi.org/10.1111/j.1467-8683.2004.00390.x

Hermalin, B. E., \& Weisbach, M. S. (1991). The effects of board composition and direct incentives on firm performance. Financial Management, 20(4), 101-112. https://doi.org/10.2307/3665716

Hussainey, K., \& Aljifi, K. (2012). Corporate governance mechanisms and capital structure in UAE. Journal of Applied Accounting Research, 13(2), 145-160. https://doi.org/10.1108/MBE-09-2016-0047

Jackling, B., \& Johl, S. (2009). Board structure and firm performance: Evidence from India's top companies. Corporate Governance, 17(4), 492-509. https://doi.org/10.1111/j.1467-8683.2009.00760.x

Jaffar, R., \& Abdul-Shukor, Z. (2016). The role of monitoring mechanisms towards company's performance. Journal of Accounting in Emerging Economies, 6(4), 408-428. https://doi.org/10.1108/JAEE-05-2014-0021

Jensen, M. C. (1986). Agency costs of free cash flow, corporate finance, and takeovers. The American Economic Review, 76(2), 323-329. https://doi.org/10.2139/ssrn.99580

Jensen, M., \& Meckling, W. (1976). Theory of the firm: managerial behavior, agency costs, and ownership structure. Journal of Financial Economics, 3(4), 305-360. https://doi.org/10.1017/CBO9780511817410.023

Kumar, S., Colombage, S., \& Rao, P. (2017). Research on capital structure determinants: a review and future directions. International Journal of Managerial Finance, 13(2), 106-132. https://doi.org/10.1108/IJMF-09-2014-0135

Margaritis, D., \& Psillaki, M. (2010). Capital structure, equity ownership and firm performance. Journal of Banking \& Finance, 34(3), 621-632. https://doi.org/10.1016/j.jbankfin.2009.08.023

Maug, E. (1997). Boards of directors and capital structure: Alternative forms of corporate restructuring. Journal of Corporate Finance, 3, 113-139. https://doi.org/10.1016/S0929-1199(96)00010-7

Mishra, C. S., \& Nielsen, J. F. (2000). Board independence and compensation policies in large bank holding companies. Financial Management, 29(3), 51. https://doi.org/10.2307/3666229

Modigliani, F., \& Miller, M. H. (1958). The cost of capital, corporation finance and the theory of investment. The American Economic Review, 48(3), 261-297.

Myers, S. C. (1984). The capital structure puzzle. The Journal Finance, 39(3), 575-592. https://doi.org/10.2307/2327916 
Myers, S. C., \& Majluf, N. S. (1984). Corporate financing and investment decisions when firms have information that investors do not have. Journal of Financial Economic Policy, 13(2), 187-221.

https://doi.org/10.1016/0304-405X(84)90023-0

Pearce, J. A., \& Zahra, S. A. (1992). Board compensation from a strategic contingency perspective. Journal of Management Studies, 29(4), 411-438. https://doi.org/10.1111/j.1467-6486.1992.tb00672.x

Petersen, M. A., \& Rajan, R. G. (1994). The Benfits of Lending Relationships: Evidence from Small Business Data. Journal of Finance, 49(1), 3-37. https://doi.org/10.1111/j.1540-6261.1994.tb04418.x

Rajan, R. G., \& Zingales, L. (1995). What Do We Know about Capital Structure? Some Evidence from International Data What Do We Know about Capital Structure? Some Evidence from International Data. Source: The Journal of Finance the Journal of Finance, 50(5), 1421-1460. https://doi.org/10.2307/2329322

Reddy, K., \& Locke, S. (2014). The relationship between ownership structure, capital structure and corporate governance practices:A case study of co-operatives and mutuals in New Zealand. International Journal of Managerial Finance, 10(4), 511-536. https://doi.org/10.1108/lJMF-12-2012-0130

Reddy, K., Locke, S., \& Scrimgeour, F. (2010). The efficacy of principle-based corporate governance practices and firm financial performance. International Journal of Managerial Finance, 6(3), 190-219. https://doi.org/10.1108/17439131011056224

Rocca, M. La. (2007). The influence of corporate governance on the relation between capital structure and value. Corporate Governance: The International Journal of Business in Society, 7(3), 312-325 https://doi.org/10.1108/14720700710756580

Ross, M. P. (1997). Dynamic Optimal Risk Management and Dividend Policy under Optimal Capital Structure and Maturity. Working Paper, University of California at Berkeley.

Ross, S. A. (1977). The Determination of Financial Structure: The Incentive Signalling Approach. Bell Journal of Economics, 8(1), 23-40. https://doi.org/10.2307/3003485

Shan, Y. G., \& Xu, L. (2012). Bad debt provisions of financial institutions. International Journal of Managerial Finance, 8(4), 344-364. https://doi.org/10.1108/17439131211261260

Shleifer, A., \& Vishny, R. W. (1997). A survey of corporate governance. The Journal of Finance, 52(2), 737-783. https://doi.org/10.1111/j.1540-6261.1974.tb00057.x

Shyu, J. (2013). Ownership structure, capital structure, and performance of group affiliation: Evidence from Taiwanese group-affiliated firms. Managerial Finance, 39(4), 404-420. https://doi.org/10.1108/MBE-09-2016-0047
Su, K. D. (2010). Ownership structure, corporate diversification and capital structure: Evidence from China's publicly listed firms. Management Decision, 48(2), 314-339. https://doi.org/10.1108/MBE-09-2016-0047

Sulaiman, N. A. (2017). Oversight of audit quality in the UK: insights into audit committee conduct. Meditari Accountancy Research, 25(3), 351-367. https://doi.org/10.1108/MEDAR-08-2016-0074

Tabacknick, B. G., \& Fidell, L. S. (1996). Using multivariate statistic (3rd ed.). New York: Harpour collings collers publishers.

Tarus, D. K., \& Ayabei, E. (2016). Board composition and capital structure: evidence from Kenya. Management Research Review, 39(9), 1056-1079. https://doi.org/10.1108/MRR-01-2015-0019

Van Essen, M., Engelen, P. J., \& Carney, M. (2013). Does "good" corporate governance help in a crisis? The impact of countryand firm-level governance mechanisms in the European financial crisis. Corporate Governance: An International Review, 21(3), 201-224. https://doi.org/10.1111/corg. 12010

White, H. (1980). A heteroskedasticity-consistent covariance matrix estimator and a direct test for heteroskedasticity. Econometrica, 48(4), 817-838. https://doi.org/10.2307/1912934

Williamson, O. (1984). Corporate Governance. The Yale Law Journal, 93(7), 1197-1230. https://doi.org/10.2307/796256

Wiwattanakantang, Y. (2001). Controlling Shareolders and Corporate Value: Evidence from Thailand. Pacific Basin Finance Journal (Vol. 9). https://doi.org/10.1016/S0927-538X(01)00022-1

Wu, R. (2012). Does Corporate Governance Quality Lend Credibility to Open-Market Share Repurchase Announcements? Corporate Governance : An International Review, 20(5), 490508. https://doi.org/10.1111/corg.12003

Yu, B. (2012). Agency costs of stakeholders and capital structure: international evidence. Managerial Journal, 38(3), 303-324. https://doi.org/10.1108/MBE-09-2016-0047

Zaitul, \& Ilona, D. (2018). Gender in Audit Committee and Financial Reporting Timeliness: the Case of Unique Continental European Model. International Journal of Engineering \& Technology, 7(2.29), 436-442. https://doi.org/10.14419/ijet.v7i2.29.13668

Zaitul, \& Ilona, D. (2019). Tax Aggressiveness and Politically Connected Company. In The 1st Economics, Law, Education and Humanties Internaltional Conference (Vol. 2019, pp. 1019). https://doi.org/10.18502/kss.v3i14.4294

Zwiebel, J. (1996). Dynamic capital structure under management entrenchment. American Economic Review, 86(5), 11971215. https://doi.org/10.2307/2118286

\section{DOI: https://doi.org/10.6000/1929-7092.2019.08.63}

(C) 2019 Ilona et al.; Licensee Lifescience Global.

This is an open access article licensed under the terms of the Creative Commons Attribution Non-Commercial License (http://creativecommons.org/licenses/by-nc/3.0/) which permits unrestricted, non-commercial use, distribution and reproduction in any medium, provided the work is properly cited. 